\title{
On the Stability of a Fully Instrumented River Embankment Under Transient Conditions
}

\author{
Gragnano, C.G.; Bertolini, I.; Rocchi, Irene; Gottardi, G.
}

Published in:

Geotechnical Research for Land Protection and Development: Proceedings of CNRIG 2019

Link to article, DOI:

10.1007/978-3-030-21359-6_39

Publication date:

2020

Document Version

Peer reviewed version

Link back to DTU Orbit

Citation $(A P A)$ :

Gragnano, C. G., Bertolini, I., Rocchi, I., \& Gottardi, G. (2020). On the Stability of a Fully Instrumented River Embankment Under Transient Conditions. In Geotechnical Research for Land Protection and Development: Proceedings of CNRIG 2019 (Vol. 40, pp. 369-378). Springer. Lecture Notes in Civil Engineering Vol. 40 https://doi.org/10.1007/978-3-030-21359-6_39

\section{General rights}

Copyright and moral rights for the publications made accessible in the public portal are retained by the authors and/or other copyright owners and it is a condition of accessing publications that users recognise and abide by the legal requirements associated with these rights.

- Users may download and print one copy of any publication from the public portal for the purpose of private study or research.

- You may not further distribute the material or use it for any profit-making activity or commercial gain

- You may freely distribute the URL identifying the publication in the public portal 


\title{
On the stability of a fully instrumented river embankment under transient conditions
}

\author{
Gragnano C.G. ${ }^{* 1}$, Bertolini I. ${ }^{1}$, Rocchi . $^{2}$, and Gottardi G. ${ }^{1}$ \\ ${ }^{1}$ Department of Civil, Chemical, Environmental and Material Engineering DICAM, University of \\ Bologna \\ ${ }^{2}$ Department of Civil Engineering, Technical University of Denmark. \\ * corresponding author: carmine.gragnano2@unibo.it
}

\begin{abstract}
Time-dependent boundary conditions, uncertainties and variability of soil suction and water content of the filling material together with the use of proper retention and strength soil models are crucial aspects to be included for reliable analyses of the actual stability of river embankments. However, due to a typical lack of information in many practical cases, the use of simplistic assumptions on both hydraulic and mechanical response of earth infrastructures to hydrometric water level fluctuation and atmospheric loading is largely diffused, thus providing erroneous conclusions on the effective safety margins towards possible slope instability and collapse. Within this context, site measurements down to relevant depths, combined to an accurate soil characterization under partially saturated conditions, can be extremely useful to evaluate unsaturated variables (i.e. soil water content and suction) under transient flow conditions and hence carry out realistic stability analyses. A comprehensive monitoring system has been therefore designed and installed on a relevant representative section along river Secchia, a right-hand tributary of river Po (Northern Italy). The paper aims at presenting a methodological approach for a sustainable performance assessment of such geotechnical infrastructures, based on the complementary use of laboratory tests, field measurements and numerical analyses.
\end{abstract}

Keywords: River embankment, slope stability, field monitoring, unsaturated soil, transient flow.

\section{Introduction}

The safety conditions assessment of river earth infrastructures represents a critical issue for both geotechnical and environmental engineering and becomes a crucial aspect, in the framework of hydrogeological instability, for land-use planning and flood risk management. In particular, the Emilia Romagna region, with a territorial extension of $22452 \mathrm{~km}^{2}$, has the highest portion of territory in danger for flood hazard (ISPRA, 2018). The sudden collapse of embankment sections of Secchia, Enza e Panaro rivers between 2014 (Fig. 1) and 2017, the very recent collapse of Reno river em- 